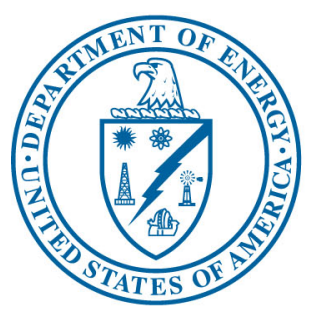

U.S. Department of Energy

Idaho Operations Office

\title{
INL Site Executable Plan for Energy and Transportation Fuels Management
}

November 2008

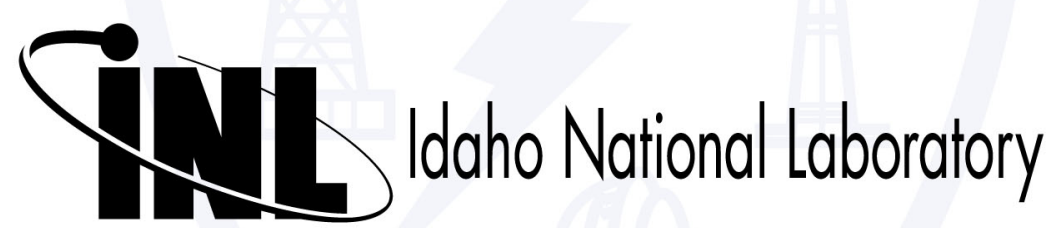




\title{
INL Site Executable Plan for Energy and Transportation Fuels Management
}

\author{
Ernest L. Fossum
}

November 2008

Prepared for the 
(This Page Intentionally Left Blank) 
(This Page Intentionally Left Blank) 


\begin{tabular}{|c|c|c|c|c|}
\hline$\left(\frac{2}{61}\right)$ & \multicolumn{4}{|c|}{$\begin{array}{c}\text { DOE ORDER 430.2B INL SITE EXECUTABLE PLAN } \\
\text { TEAM GOAL SUMMARY }\end{array}$} \\
\hline Goal Elements & $\begin{array}{c}\text { Plan Meets } \\
\text { Goal }\end{array}$ & $\begin{array}{l}\text { Plan } \\
\text { Exceeds } \\
\text { Goal }\end{array}$ & $\begin{array}{l}\text { Plan Falls } \\
\text { Short of } \\
\text { Goal }\end{array}$ & Comments \\
\hline Energy Efficiency & $\sqrt{ }$ & $\Gamma$ & $\Gamma$ & $\begin{array}{l}\text { This version of the Executable Plan provides } \\
\text { a high level analysis on strategies to meet } \\
\text { the energy efficiency goals for the INL Site. } \\
\text { Since the ESPC or UESC projects have not } \\
\text { been developed by the Energy Services } \\
\text { Companies or Utilities, and since new } \\
\text { process facilities may consume significant } \\
\text { energy to perform their functions, more } \\
\text { detailed evaluations in the next year or two } \\
\text { may reveal areas where the INL Site may } \\
\text { exceed or fall short of the energy efficiency } \\
\text { goals. This Plan will be updated annually to } \\
\text { reflect new opportunities and issues as they } \\
\text { are identified. }\end{array}$ \\
\hline Renewable Energy & $\sqrt{\nabla}$ & $\Gamma$ & $\Gamma$ & $\begin{array}{l}\text { This version of the Executable Plan provides } \\
\text { a high level analysis on strategies to meet } \\
\text { the Renewable Energy goals for the INL Site. } \\
\text { Since the analyses are still in process by } \\
\text { NREL and the results will be forwarded to } \\
\text { the Energy Services Companies and Utilities, } \\
\text { Renewable Energy projects have not yet } \\
\text { been identified or developed. However, } \\
\text { plans to purchase RECs at the minimum } \\
\text { required amounts are in place. This Plan will } \\
\text { be updated annually to reflect new } \\
\text { opportunities and issues as they are } \\
\text { developed. }\end{array}$ \\
\hline Water & $\sqrt{\varnothing}$ & $\Gamma$ & $\Gamma$ & $\begin{array}{l}\text { This version of the Executable Plan provides } \\
\text { a high level analysis on strategies to meet } \\
\text { the Water Reduction goals for the INL Site. } \\
\text { Since the ESPC or UESC projects have not yet } \\
\text { been developed by the Energy Services } \\
\text { Companies or Utilities, and since a Water } \\
\text { Leak Analysis is expected to be completed in } \\
\text { FY 2009, INL Site may exceed or fall short of } \\
\text { the Water Reduction goals. This Plan will be } \\
\text { updated annually to reflect new } \\
\text { opportunities and issues as they are } \\
\text { identified. }\end{array}$ \\
\hline
\end{tabular}




\begin{tabular}{|c|c|c|c|c|}
\hline (1) & \multicolumn{4}{|c|}{$\begin{array}{c}\text { DOE ORDER 430.2B INL SITE EXECUTABLE PLAN } \\
\text { TEAM GOAL SUMMARY }\end{array}$} \\
\hline Goal Elements & $\begin{array}{c}\text { Plan Meets } \\
\text { Goal }\end{array}$ & $\begin{array}{l}\text { Plan } \\
\text { Exceeds } \\
\text { Goal }\end{array}$ & $\begin{array}{l}\text { Plan Falls } \\
\text { Short of } \\
\text { Goal }\end{array}$ & Comments \\
\hline $\begin{array}{c}\text { Transportation } \\
\text { Fuels Management }\end{array}$ & $\sqrt{V}$ & $\Gamma$ & $\Gamma$ & $\begin{array}{l}\text { This version of the Executable Plan provides } \\
\text { a high level analysis on strategies to meet } \\
\text { the transportation and fleet management } \\
\text { goals for the INL Site. The strategies } \\
\text { outlined depend on the availability of } \\
\text { alternative fuels at cost competitive prices in } \\
\text { the Idaho Falls area, on either ESPCS or DOE } \\
\text { funding to upgrade site fueling stations, and } \\
\text { on the ability to obtain buses for the INL bus } \\
\text { fleet that are able to use alternative fuel } \\
\text { (CNG). More detailed information should be } \\
\text { available for the update to this plan in } \\
\text { FY } 2010 \text {. This Plan will be updated annually } \\
\text { to reflect new opportunities and issues as } \\
\text { they are identified. }\end{array}$ \\
\hline $\begin{array}{l}\text { High Performance } \\
\text { and Sustainable } \\
\text { Buildings }\end{array}$ & $\sqrt{\checkmark}$ & $\Gamma$ & $\Gamma$ & $\begin{array}{l}\text { This version of the Executable Plan provides } \\
\text { a high level analysis on strategies to meet } \\
\text { the High Performance and Sustainable } \\
\text { Buildings goals for the INL Site. The INL site } \\
\text { has prioritized existing buildings for } \\
\text { consideration of upgrades to incorporate the } \\
\text { Guiding Principles through ESPC or UESC as } \\
\text { well as through normal DOE funded } \\
\text { maintenance projects. Since those projects } \\
\text { and contracts have not yet been designed or } \\
\text { negotiated, the results cannot be accurately } \\
\text { projected. This Plan will be updated annually } \\
\text { to reflect more detailed information and } \\
\text { projections. }\end{array}$ \\
\hline
\end{tabular}




\title{
INL SITE Executable Plan for Energy and Transportation Fuels Management
}

\author{
DOE/ID-11383 \\ Revision 0
}

November 2008

Approved by

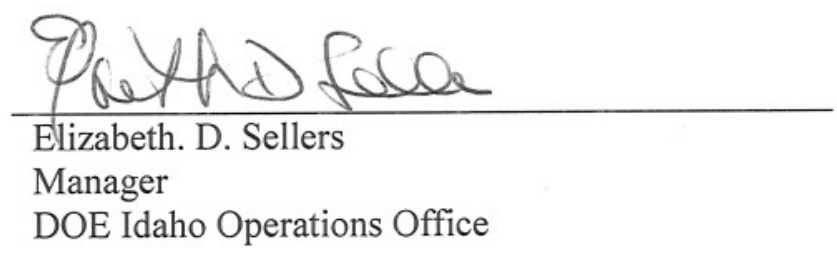

$\frac{4 / 14 / 08}{\text { Date }}$

Manager

DOE Idaho Operations Office 
(This Page Intentionally Left Blank) 


\section{INL SITE Executable Plan for \\ Energy and Transportation Fuels Management}

DOE/ID-11383

Revision 0

November 2008

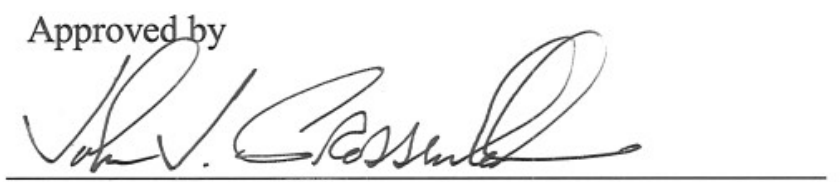

John J. Grossenbacher

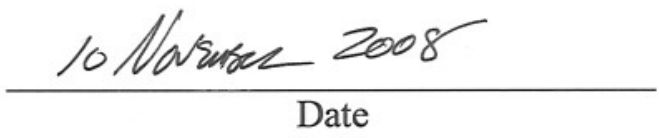

Director, Idaho National Laboratory and

President, Battelle Energy Alliance, LLC 
(This Page Intentionally Left Blank) 


\title{
INL SITE Executable Plan for Energy and Transportation Fuels Management
}

\author{
DOE/ID-11383 \\ Revision 0
}

November 2008
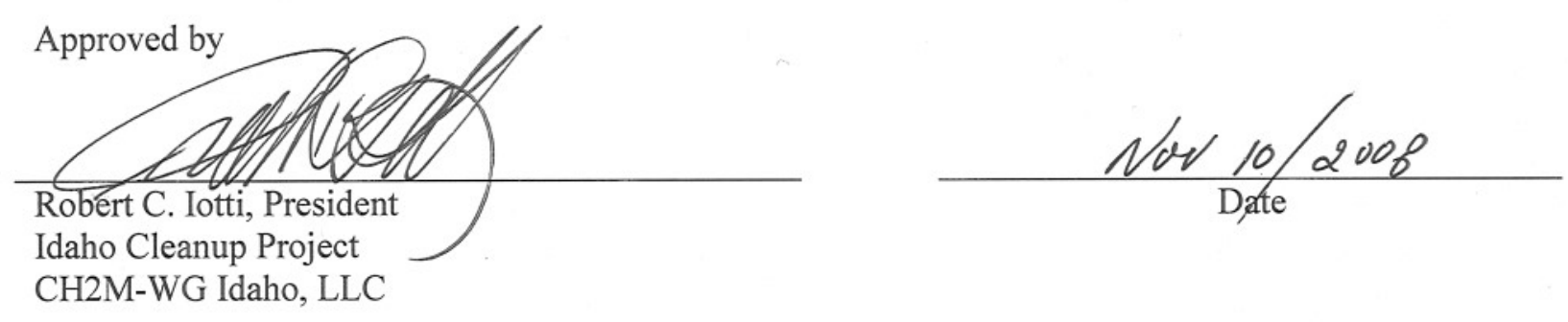
(This Page Intentionally Left Blank) 


\title{
INL SITE Executable Plan for Energy and Transportation Fuels Management
}

\author{
DOE/ID-11383 \\ Revision 0
}

November 2008

Approved by

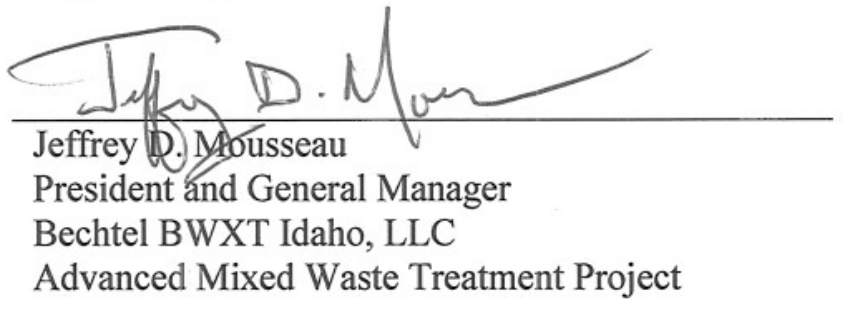

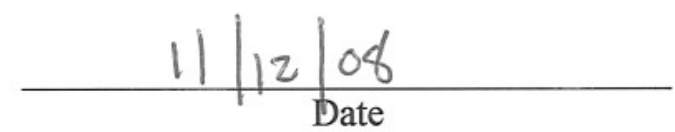


(This Page Intentionally Left Blank) 


\section{CONTENTS}

EXECUTIVE SUMMARY ..............................................................................................................

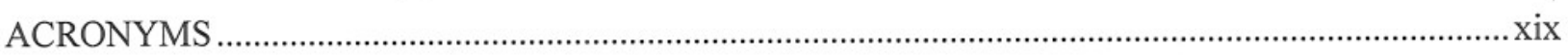

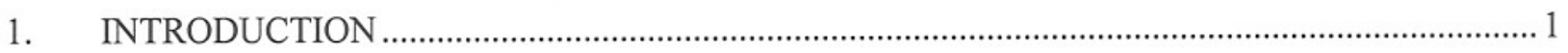

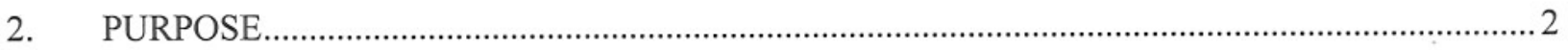

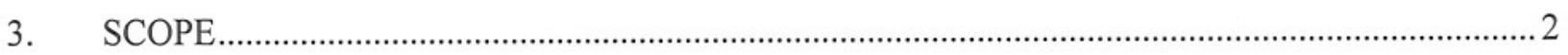

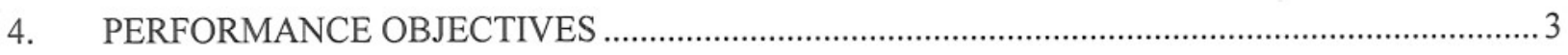

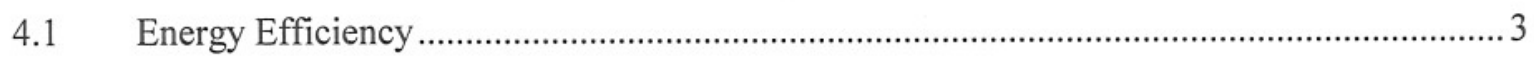

4.1.1 Energy Efficiency ..................................................................................... 3

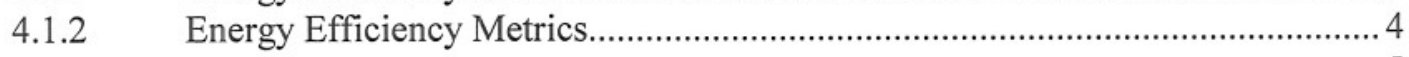

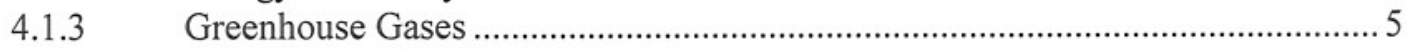

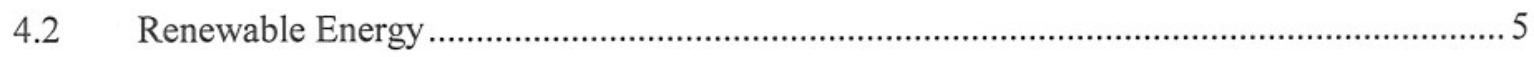

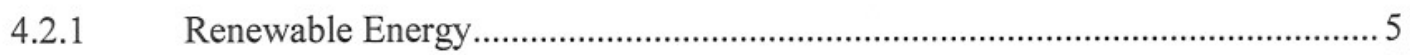

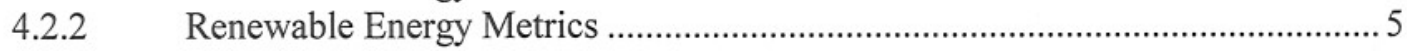

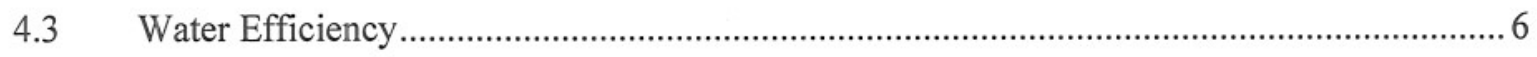

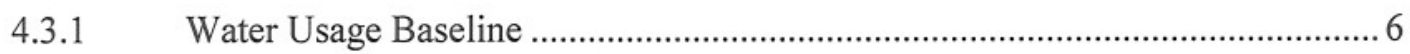

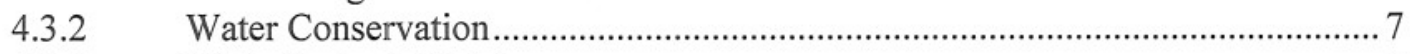

4.3.3 Water Projects Metrics ............................................................................ 7

4.4 Transportation Fuels Management ……........................................................................ 8

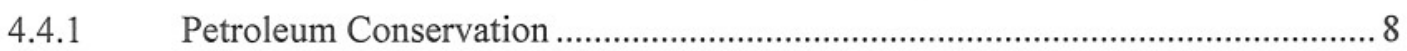

4.4.2 Alternative Fuel Use............................................................................... 9

4.4.3 Alternative Fuel Vehicles.......................................................................... 10

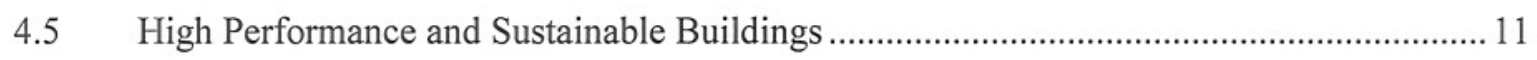

4.5.1 New Buildings and Major Renovations ....................................................... 11

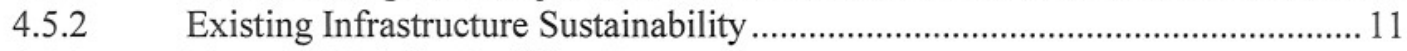

4.5.3 New and Existing Building Leases ........................................................... 12

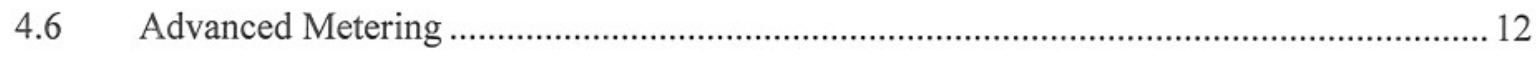

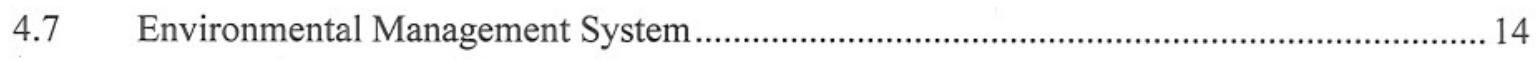

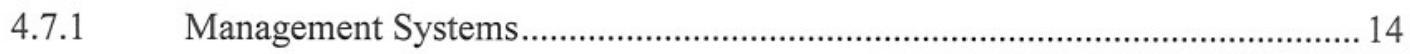

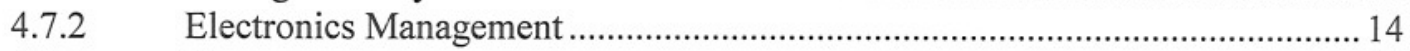

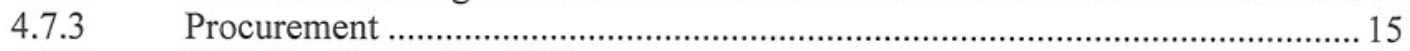

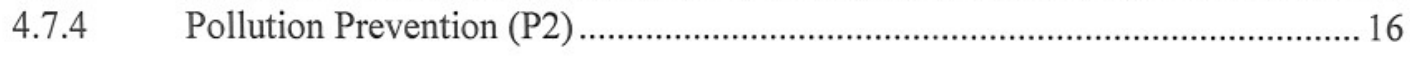


5. EMERGENCY CONSERVATION PLANS .......................................................................... 16

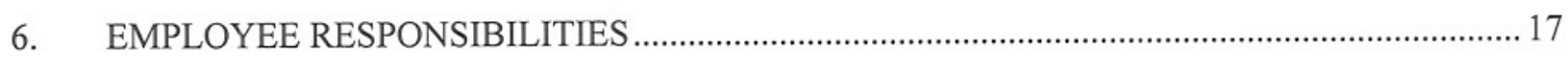

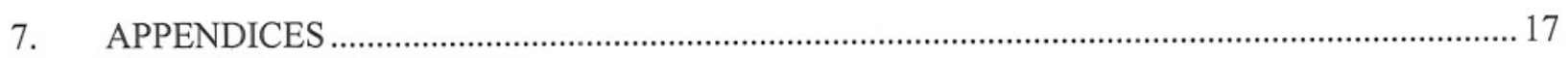

\section{TABLES}

Table 1. Estimated Future Energy Reduction Projects ........................................................................ 4

Table 2. Planned REC Purchases for the INL Site ...................................................................... 6

Table 3. Estimated Future Water Reduction Projects ......................................................................... 8

Table 4. List of Buildings Selected for Advanced Meter Installation Consideration. ............................. 13 


\section{EXECUTIVE SUMMARY}

It is the policy of the Department of Energy (DOE) that sustainable energy and transportation fuels management will be integrated into DOE operations to meet obligations under Executive Order (EO) 13423 "Strengthening Federal Environmental, Energy, and Transportation Management", the Instructions for Implementation of EO 13423, as well as Guidance Documents issued in accordance thereto and any modifications or amendments that may be issued from time to time. In furtherance of this obligation, DOE established strategic performancebased energy and transportation fuels goals and strategies through the Transformational Energy Action Management (TEAM) Initiative, which were incorporated into DOE Order 430.2B "Departmental Energy, Renewable Energy, and Transportation Management" and were also identified in DOE Order 450.1A, "Environmental Protection Program". These goals and accompanying strategies are to be implemented by DOE sites through the integration of energy and transportation fuels management into site Environmental Management Systems (EMS).

This document presents the INL Site Executable Plan for Energy and Transportation Fuels Management pursuant to DOE Orders 430.2B and 450.1A. The Plan was prepared in accordance with the DOE "Guidance for Developing the Executable Plan". The activities and operations at the Naval Reactor Facility, located on the INL Site, are specifically excluded from this Plan.

The work at the INL Site is currently managed through three major contracts, each with a very different work scope and contract type. Some projects will have a much more limited scope to accomplish under the Executable Plan. The Idaho National Laboratory contract is funded through the Office of Nuclear Energy (NE) and others including the National Nuclear Security Administration (NNSA), Office of Energy Efficiency (EE), and Work for Others (WFO) and encompasses the site bus fleet, the electric power distribution system to each of the facility areas, and includes operation of the Advanced Test Reactor (ATR) Complex, Manufacturing and Fuels Complex (MFC), Central Facilities Area (CFA), Critical Infrastructure Test Research Complex (CITRC), and the Research and Education Complex (REC) facilities under their control. In addition, any renewable energy generation projects would likely fall within the scope of the INL contract. The INL contractor has been the point of consolidation for INL Site energy management reporting.

The Office of Environmental Management (EM) funded projects at the INL Site are the Idaho Completion Project (ICP) and the Advanced Mixed Waste Treatment Project (AMWTP). The ICP is responsible for the remainder of the EM funded cleanup and closure work at the INL Site. The AMWTP scope is to retrieve, repackage, treat, and ship certain transuranic (TRU) waste stored at the INL Site, primarily the TRU waste stored on above ground pads at the Radioactive Waste Management Complex (RWMC). Due to the nature of the work, neither of these projects or contracts are intended to expand in scope or build significant new buildings or processes except as required (such as the Integrated Waste Treatment Unit and the Accelerated Retrieval Project) to complete the cleanup of legacy waste and Decontamination and Decommissioning (D\&D) of obsolete processes and facilities. They have minimal or no infrastructure obligations outside of their defined facility areas. Therefore their obligations in the Plan are limited to operation, maintenance, construction, and renovation of buildings and processes within their area of control and of fleet transportation within their direct control.

The purpose of this Plan is to meet the requirements of the Energy Policy Act of 2005 (EPAct 2005), and the DOE Orders $430.2 \mathrm{~B}$ and $450.1 \mathrm{~A}$ by increasing the sustainability of INL Site operations and reducing or eliminating energy waste without compromising the overall missions of the INL Site. The success of the program is dependent on financial and management support. The signatures on the previous page indicate DOE Idaho Operations Office (DOE-ID), INL, ICP, and AMWTP Contractor management commitment to this Plan. 
(This Page Intentionally Left Blank) 


\section{ACRONYMS}

\begin{tabular}{|c|c|}
\hline AFV & Alternative Fuel Vehicle \\
\hline AMWTP & Advanced Mixed Waste Treatment Project \\
\hline ATR & Advanced Test Reactor (entire area is now called the ATR Complex) \\
\hline B20 & Biodiesel 20 (alternative fuel that is $20 \%$ biodiesel and $80 \%$ conventional diesel) \\
\hline Btu & British thermal unit \\
\hline DOE-ID & U.S. Department of Energy Idaho Operations Office \\
\hline CFA & Central Facilities Area \\
\hline CITRC & Critical Infrastructure Test Research Complex \\
\hline CNG & Compressed Natural Gas \\
\hline E85 & Ethanol 85 (alternative fuel that is $85 \%$ ethanol and $15 \%$ gasoline) \\
\hline EMS4 & Energy Management System 4 (FEMP energy data collection system) \\
\hline ESPC & Energy Savings Performance Contract \\
\hline FEC & Federal Electronics Challenge \\
\hline FEMP & Federal Energy Management Program \\
\hline FIMS & Facilities Information Management System \\
\hline GSA & General Services Administration \\
\hline ICP & Idaho Cleanup Project \\
\hline INL & Idaho National Laboratory \\
\hline INTEC & Idaho Nuclear Technology and Engineering Center \\
\hline IRC & INL Research Center \\
\hline LEED $^{\text {TM }}$ & Leadership in Energy \& Environmental Design (green building design certification) \\
\hline LNG & Liquefied Natural Gas \\
\hline MFC & Materials and Fuels Complex \\
\hline NREL & National Renewable Energy Laboratory \\
\hline REC & Renewable Energy Credit \\
\hline TEAM & Transformational Energy Action Management (TEAM) Initiative \\
\hline UESC & Utility Energy Services Contract \\
\hline
\end{tabular}


(This Page Intentionally Left Blank) 


\section{INTRODUCTION}

Executive Order 13423 "Strengthening Federal Environmental, Energy, and Transportation Management" establishes requirements to cost effectively meet or exceed the goals and objectives of the Energy Policy Act of 2005 for energy efficiency, use of renewable energy, transportation energy, and water conservation at Federal facilities. The new DOE Order 430.2B "Departmental Energy, Utilities, and Transportation Management" contains requirements that the Department of Energy will accomplish to implement Executive Order 13423. The DOE Idaho Operations Office identifies and communicates specific performance objectives and targets to the INL Site contractors via performance agreements and/or other contractual direction.

DOE Order 430.2B defines an Executable Plan as an action plan setting forth a binding obligation of the applicable Site that commits appropriate personnel resources, establishes a financing plan that prioritizes the use of life-cycle cost effective private sector financing and optimizes the application of appropriations and budgeted funds, and establishes a time line for execution coupled with specific performance measures and deliverables designed to achieve the listed requirements set forth in Section 1(b).

The "INL Site Executable Plan for Energy and Transportation Fuels Management", hereafter referred to as the Plan, contains strategies and activities that will lead to continual energy efficiency, environmental improvements, and transportation fuels efficiency to move the INL Site toward meeting the goals and requirements of Executive Order 13423, DOE Order 430.2B, and DOE 450.1A before the end of FY 2015. The Plan includes references to DOE/ID-10333, "INL Site Pollution Prevention Plan" to address the procurement and environmental aspects of the Orders. The Plan also summarizes energy and fuel use reporting requirements and references criteria for performing sustainable design. Energy and transportation fuels management requirements are being integrated into the INL Site contractor Integrated Safety Management Systems (ISMS) and Environmental Management Systems (EMS) to ensure an effective EMS is integrated with each ISMS. The Energy and Transportation Fuels Management Programs are also planned to be integrated with the Ten Year Site Plan (TYSP) and operations and acquisition systems.

This DOE-ID INL Site document serves as an overall INL Site energy and transportation fuels management Executable Plan. It may be supplemented by individual INL contractor energy and transportation fuels management plans. Updates to this plan are anticipated annually with added specificity as projects are developed and requirements change. This Plan encompasses all contractors and activities at the INL Site under the control of the DOE-ID Operations Office, and excludes the Naval Reactors Facility (NRF).

DOE-ID and the INL Site contractors are utilizing their existing EMS to establish goals, track, and review progress towards meeting the energy efficiency, water conservation, greenhouse gas reduction, and renewable energy goals as reflected in this plan and as flowed down in the contractor specific plans that may be established in FY 2009.

DOE Orders 430.2B and 450.1A were issued more than five months into FY 2008. The mechanism for placing the Order requirements into existing contracts takes some time as the costs for the new scope must be established and negotiated. Therefore, the INL Site contractors have had little time to define detailed plans or cost estimates for stewardship projects. However, good progress has been made to identify projects and general scope that would lend itself to Energy Savings Performance Contracts (ESPC) or Utility Energy Savings Contracts (UESC) in addition to the ESPC project identified for MFC in FY 2008. The FY 2010 updated Executable Plan will contain greater detail and better defined projects to meet the TEAM Initiative and DOE Order goals. 
The INL Site, as a whole, spent over \$11.7 million in FY 2007 for facility and equipment energy. Of this total, $\$ 11.2$ million was spent for building energy and $\$ 500 \mathrm{k}$ was spent on equipment fuel. The managed area consumes over 1.08 trillion Btu of energy and over 1 billion gallons of water annually. Energy consumption at the INL Site through FY 2007 on a Btu/ $\mathrm{ft}^{2}$ basis has been reduced by $6.6 \%$ when compared to the base year FY 2003.

Transportation fuel use across the INL Site totaled over 1 million gallons of various types of fuels during FY 2007. The INL fleet is comprised of light duty vehicles fueled by gasoline, E85, LNG, and CNG. Heavy-duty vehicles include over-the-road buses fueled by diesel, biodiesel, and LNG, and a complex assortment of trucks and equipment. Typically, 9.5 million miles are driven annually and over 50,000 hours are logged on heavy equipment.

\section{PURPOSE}

The primary purpose of this Plan is to meet the goals and requirements of DOE Orders 430.2B and 450.1A, and the TEAM Initiative by reducing energy, water, and transportation fuels use without compromising productivity and while minimizing negative impacts to employees and programs.

The secondary purpose of this Plan is to permanently establish a philosophy of sustainable building operation and design, and to firmly establish a culture of maximizing the use of alternative fuels while reducing the INL Site dependence on petroleum fuels for both facilities and vehicles.

\section{SCOPE}

The overall strategic plan is to obtain measured and verified energy and water savings as required by Executive Order 13423 and DOE Order 430.2B and as needed to increase the INL's energy and fuels stewardship by addressing the following goal elements:

- Energy Efficiency - Including implementing Energy Conservation Measures, improving building operations, and providing regular and measurable progress toward meeting the goals of Executive Order 13423 and DOE Order 430.2B.

- Renewable Energy - Including purchasing Renewable Energy Credits (RECs) and analyzing the opportunities and cost effectiveness of installing on-site renewable generation.

- Water Efficiency - Including finalizing the INL's water usage baseline, identifying cost effective water reduction opportunities, and implementing water reduction opportunities using the ESPC or UESC funding vehicles.

- Transportation Fuels Management - Primarily focusing on cost effective methods of reducing petroleum based fuels while increasing the use of alternative fuels.

- High Performance and Sustainable Buildings - Including establishing a culture of cost effective sustainable design of new facilities and major renovations.

- Energy Savings Performance Contracts (ESPC) and Utility Energy Savings Contracts (UESC) development for all project opportunities.

- Metering for potable water, electricity, and thermal energy and use of the metered information to reduce or eliminate water and energy waste. 
- Environmental Management Systems - The DOE-ID and contractor EMS programs are used to establish, track, and review the INL Site progress towards meeting the energy efficiency, water conservation, greenhouse gas reduction, and renewable energy goals.

- Other Program Objectives - Including reports as required for INL Site energy use and program performance validation including quarterly and annual energy use reports, monthly program reports to DOE-ID, and bi-annual project status reports to the Federal Energy Management Program (FEMP) at a minimum.

\section{PERFORMANCE OBJECTIVES}

\subsection{Energy Efficiency}

\subsubsection{Energy Efficiency}

Reduce energy intensity $\left(\mathrm{Btu} / \mathrm{ft}^{2}\right)$ by $3 \%$ each fiscal year as compared to the established FY 2003 baseline and/or a total of $30 \%$ by the end of FY 2015. At the end of FY 2007, the INL Site was at a reduction level of $6.6 \%$ as compared to the expected reduction level of 6\% from the FY 2003 baseline.

Strategies to accomplish the full $30 \%$ energy use reduction may include, but are not limited to:

- Implement/construct the approved MFC ESPC project prior to the end of FY 2011. This project will contribute approximately $5.6 \%$ towards the $30 \%$ goal for a total of $12.2 \%$ when added to the INL's current $6.6 \%$ reduction.

- Identify, prioritize by cost effectiveness, develop, and implement additional ESPC and/or UESC projects as needed to obtain an additional $18 \%$ reduction and reach the 30\% goal by FY 2015.

Notes: It is anticipated that at least one additional project contributing at least $6 \%$ in energy reductions needs to be developed and approved in FY 2010, 2011, and 2012 in order to complete all construction and obtain verified energy savings by the end of FY 2015.

The ATR Complex has been identified as the candidate for the next ESPC, while the Idaho Nuclear Technology and Engineering Center (INTEC) is a likely candidate to develop and evaluate a UESC project by ICP.

INL experience indicates ESPCs usually take approximately 1-2 years to develop and up to 3 additional years to construct. They are generally considered long-term solutions that will provide full savings only after they have been completed. Partial savings are realized as the project continues through the construction phases.

- Provide contractor Measurement and Verification (M\&V) oversight for the length of the contract terms for each ESPC project including the existing INL Research Center (IRC) ESPC Project \#1.

- Work regularly with INL Site contractors to develop additional project opportunities and to increase the operational efficiency of existing facilities.

- Promote Operations and Maintenance (O\&M) best practices. http://www1.eere.energy.gov/femp/operations_maintenance/om bpguide.html 
- Retro-commission the IRC Office Building (REC-602) as part of a planned upgrade study and project.

- Have the INL Site contractors prepare periodic communication regarding energy efficiency for distribution to all employees. This communication, as the core of the INL Site's employee awareness program, will lead to increased employee involvement and promote sustainable administrative energy savings.

- Maintain a prioritized list of potential energy efficiency projects to be addressed when internal and/or alternative funding is available.

- Secure other funding and incentive opportunities such as FEMP direct funding, Idaho Power Industrial Incentive funding, and Idaho Falls Power project implementation funding.

\subsubsection{Energy Efficiency Metrics}

Table 1 summarizes one planned energy efficiency project and estimates future projects (in gray italics). Note that INL Site is planning to implement the majority of the energy efficiency improvements through ESPC and/or UESC projects.

Table 1. Estimated Future Energy Reduction Projects

\begin{tabular}{|c|c|c|c|c|c|c|}
\hline & & 2003 & \multicolumn{2}{|c|}{2007} & \multicolumn{2}{|r|}{2015} \\
\hline \multicolumn{2}{|c|}{ Gross Square Feet } & $5,592,500$ & \multicolumn{2}{|c|}{$5,731,600$} & \multicolumn{2}{|c|}{$5,473,304$} \\
\hline \multicolumn{2}{|c|}{$\begin{array}{l}\text { Total Buildings Energy Use } \\
\text { (MBtu/ft }{ }^{2} \text { and Total MBtu) }\end{array}$} & $\begin{array}{l}.183 \mathrm{MBtu} / \mathrm{ft}^{2} \\
1,026,100 \mathrm{MBtu}\end{array}$ & \multicolumn{2}{|c|}{$\begin{array}{l}.171 \mathrm{MBtu}^{\prime} \mathrm{ft}^{2} \\
981,300 \mathrm{MBtu}\end{array}$} & \multicolumn{2}{|c|}{$\begin{array}{l}.128 \mathrm{MBtu}_{\mathrm{Aft}}{ }^{2} \\
702,280 \mathrm{MBtu}\end{array}$} \\
\hline $\begin{array}{c}\text { Project or separate } \\
\text { Energy } \\
\text { Conservation } \\
\text { Measure }\end{array}$ & $\begin{array}{l}\text { Actual or } \\
\text { Estimated } \\
\text { Energy } \\
\text { Saved } \\
\text { MBtulyr }\end{array}$ & $\begin{array}{c}\text { Actual or } \\
\text { Estimated } \\
\text { Implementation } \\
\text { Cost }\end{array}$ & $\begin{array}{l}\text { Expected Year of } \\
\text { Implementation }\end{array}$ & $\begin{array}{r}F \\
\text { Sour } \\
\text { OV } \\
\text { GP }\end{array}$ & PC, & $\begin{array}{c}\text { For ESPCs, } \\
\text { Expected } \\
\text { Date of } \\
\text { Delivery } \\
\text { Order } \\
\text { Award }\end{array}$ \\
\hline INL Project \#2 (MFC) & 53,362 & $\$ 33.3 \mathrm{M}$ & FY 2011 & & & FY 2008 \\
\hline INL Project \#3 & 75,219 & $\sim \$ 34.3 \mathrm{M}$ & FY 2012 & $E S P$ & ESC & FY 2010 \\
\hline INL Project \#4 & 75,219 & $\sim \$ 35.3 \mathrm{M}$ & FY 2013 & $E S P$ & ESC & FY 2011 \\
\hline INL Project \#5 & 75,219 & $\sim \$ 36.4 \mathrm{M}$ & FY 2014 & $E S P$ & ESC & FY 2012 \\
\hline
\end{tabular}

Notes: 1) ESPC and UESC projects are the primary methods that the INL Site will employ to implement energy reduction opportunities.

2) Square footage for FY 2015 is based on the INL's Ten-Year Site Plan and includes D\&D and new construction.

3) As the INL Site mission changes and new buildings and processes are constructed that are more energy intensive, attention will be given to determining facilities or portions of facilities that should be excluded from the energy reduction goals. Examples of include new High Performance Data Centers and the INL's new Component Test Facility.

4) INL Project \#1 is an ESPC completed in FY 2000 at the INL Research Center (IRC). 


\subsubsection{Greenhouse Gases}

Reduce Greenhouse Gases by 3\% each fiscal year as compared to the established FY 2003 baseline and/or a total of 30\% by the end of FY 2015.

- Greenhouse gas reductions are calculated automatically through DOEHQ's Energy Management System 4 (EMS4) and are achieved through the energy intensity $\left(\mathrm{Btu} / \mathrm{ft}^{2}\right)$ reductions described in section 4.1.1.

\subsection{Renewable Energy}

\subsubsection{Renewable Energy}

The INL purchased Renewable Energy Credits (RECs) for the INL Site equivalent to $3 \%$ of the total INL Site electric energy usage in both FY 2007 and 2008. Costs for RECs are borne by all energy users at the INL Site. INL will continue to purchase RECs as the core method for increasing the use of renewable energy on behalf of the INL Site.

The INL has one small Solar Transpired Wall installed on the Records Storage Facility (REC-663) during initial construction in 2001. This wall provides approximately 102.4 MBtu of avoided energy use in preheat to the buildings fresh air supply. There are two additional solar walls planned as part of the MFC ESPC project. These walls will be installed on MFC-774 and MFC-782 and are calculated to provide an additional $503 \mathrm{MBtu}$ in avoided annual energy use.

The INL is also evaluating potential wind generation locations on-site by installing additional weather stations to further evaluate favorable locations, and is working with the National Renewable Energy Laboratory (NREL) to evaluate possible biomass, solar energy, and geothermal energy generation.

Strategies to increase the use of renewable energy may include, but are not limited to:

- INL to continue purchases of renewable energy or RECs in amounts relative to total INL Site electric energy usage as follows:

- $\quad 3 \%$ in FY 2008 and 2009

- $\quad 5 \%$ in FY 2010 to FY 2012, and

- $\quad 7.5 \%$ in FY 2013 and thereafter

Note: $50 \%$ of the current renewable energy purchases must be from new renewable sources in service after January 1, 1999. This is not an issue as the RECs purchased by INL have been 100\% new renewable energy.

- Evaluate potential projects that would cost effectively install on-site renewable energy that would meet or contribute to the $\%$ requirements shown above.

- Utilize the ESPC or UESC funding vehicles to implement cost-effective renewable energy generation projects.

\subsubsection{Renewable Energy Metrics}

The INL will continue to purchase Renewable Energy Credits (RECs) through FY 2015 as described in 4.2.1. An on-site Renewable Energy project has not been 
identified, however, should wind or other alternative energy be economically feasible, purchased RECs will be reduced as renewable energy is produced.

Table 2 summarizes estimated planned REC purchases.

Table 2. Planned REC Purchases for the INL Site

\begin{tabular}{|c|c|c|c|c|c|}
\hline $\begin{array}{c}\text { Renewable } \\
\text { Energy/Thermal } \\
\text { Energy } \\
\text { Technology } \\
\text { including RECs }\end{array}$ & $\begin{array}{c}\text { System } \\
\text { Size }\end{array}$ & $\begin{array}{c}\text { Total } \\
\text { MWh/yr }\end{array}$ & $\begin{array}{c}\text { Renewable } \\
\text { Energy Initial } \\
\text { Project } \\
\text { Capital Cost }\end{array}$ & $\begin{array}{c}\text { Funding } \\
\text { Source } \\
\text { (ESPC, } \\
\text { UESC, PPA, } \\
\text { Other) }\end{array}$ & $\begin{array}{c}\text { Expected Year } \\
\text { of } \\
\text { Implementation }\end{array}$ \\
\hline REC 3\% & N/A & 6,600 & $\$ 18,150$ & Indirect & 2009 \\
\hline REC 5\% & N/A & 10,300 & $\$ 29,200$ & Indirect & 2010 \\
\hline REC 5\% & N/A & 10,000 & $\$ 29,150$ & Indirect & 2011 \\
\hline REC 5\% & N/A & 9,650 & $\$ 29,950$ & Indirect & 2012 \\
\hline REC 7.5\% & N/A & 14,000 & $\$ 43,120$ & Indirect & 2013 \\
\hline REC $7.5 \%$ & N/A & 13,500 & $\$ 42,700$ & Indirect & 2014 \\
\hline REC $7.5 \%$ & N/A & 13,000 & $\$ 42,200$ & Indirect & 2015 \\
\hline
\end{tabular}

Notes: 1) Potential renewable energy generation and passive energy sources for the INL include solar, wind, and geothermal.

2) Any installation of renewable energy would be subject to a full environmental review..

\subsection{Water Efficiency}

The INL Site used approximately 1.01 billion gallons of production and potable water in FY 2007 (INL/EXT-08-14083 and FY 2007 Annual Report). Water is metered from each deep well at the desert site and metered by the City of Idaho Falls at each facility in Idaho Falls. Water costs DOE approximately $\$ 1.3$ million in annual pumping, treatment, and disposal costs. Water is relatively inexpensive at INL ( $\$ 1.21$ thousand gallons) because it is pumped on-site from an extensive aquifer.

\subsubsection{Water Usage Baseline}

Using existing metered information and correct applications of potable and process water definitions and guidance from FEMP, formalize the FY 2007 INL water usage baseline.

The INL Site is currently evaluating water usage trends and applications and is awaiting further discussion and direction from FEMP and Energy Efficiency and Renewable Energy (EERE) on potable and non-potable water use reporting designations. When these reporting issues are resolved, the INL Site will formally establish its FY 2007 baseline with existing water use metered data. The estimated baseline presented above and in Table 3. is likely to change during FY 2009. 


\subsubsection{Water Conservation}

Reduce potable water consumption intensity (gallons/ $\mathrm{ft}^{2}$ ) by $2 \%$ each fiscal year as compared to the established FY 2007 baseline for a total of $16 \%$ by the end of FY 2015.

Strategies to accomplish this $16 \%$ water use reduction may include, but are not limited to:

- Implement the MFC ESPC project, which will provide 3.5 million gallons of annual water savings or a total of $0.3 \%$ towards the $16 \%$ reduction requirement.

- Implement Water Leak Analyses on the ATR Complex, CFA, TAN, INTEC, and CITRC water and fire mains with the highest potential for leaks.

- Complete the "Operable Unit 3-14, Tank Farm Soil and INTEC Groundwater Long-Term Monitoring Plan" at INTEC as described in DOE/ID-11334.

- Use alternative funding such as ESPC or UESC, to replace existing water distribution system pumps at INTEC with lower operating range pumps or to install an improved pump recirculation system.

- From the water usage baseline and the results of the Water Leak Analyses, develop a prioritized list of potential water efficiency projects to be included in ESPC/UESC projects.

- Ensure that water use reductions and water meter installations are included in the desired work scope during the development of each of the next ESPC/UESC projects.

- Investigate and utilize other funding and incentive opportunities such as FEMP direct funding, Idaho Power Incentive funding, and Idaho Falls Power project implementation funding.

- Develop additional project opportunities and to increase water efficiency in existing facilities and processes and in external applications.

- Promote Water Management best practices during basic M\&O. http://wwwl.eere.energy.gov/femp/water/water bmp.html

- Include water reduction information in monthly energy efficiency communications distributed to all employees.

\subsubsection{Water Projects Metrics}

Table 3 summarizes planned water projects and estimated future projects (in gray: itclics). Note that this table includes estimated savings before the INL's water baseline is formally established. 
Table 3. Estimated Future Water Reduction Projects

\begin{tabular}{|c|c|c|c|c|}
\hline & & & FY 2007 & FY 2015 \\
\hline \multicolumn{3}{|c|}{ Gross Square Foot } & $5,731,600$ & $5,473,304$ \\
\hline \multicolumn{3}{|c|}{$\begin{array}{l}\text { Total Buildings Water Use } \\
\text { (gal/ft }{ }^{2} \text { and Total Mgal) }\end{array}$} & $\begin{array}{c}176.2 \mathrm{gal} / \mathrm{ft}^{2} \\
1,010.0 \mathrm{Mgal}\end{array}$ & $\begin{array}{l}148.0 \mathrm{gal} / \mathrm{ft}^{2} \\
810.1 \mathrm{Mgal}\end{array}$ \\
\hline $\begin{array}{l}\text { Project or } \\
\text { separate } \\
\text { Energy } \\
\text { Conservation } \\
\text { Measure }\end{array}$ & $\begin{array}{c}\text { Actual or } \\
\text { Estimated } \\
\text { Water } \\
\text { Saved } \\
\text { (kgal/yr) }\end{array}$ & $\begin{array}{c}\text { Expected Year } \\
\text { of } \\
\text { Implementation }\end{array}$ & $\begin{array}{c}\text { Actual or } \\
\text { Estimated } \\
\text { Implementation } \\
\text { Cost }\end{array}$ & $\begin{array}{c}\text { Funding } \\
\text { Source (ESPC, } \\
\text { UESC, } \\
\text { Overhead, } \\
\text { GPP, Other) }\end{array}$ \\
\hline $\begin{array}{l}\text { INL Project \#2 } \\
\text { (MFC) }\end{array}$ & $\begin{array}{l}3,500 \\
\mathrm{kgal} / \mathrm{yr}\end{array}$ & FY 2011 & $\begin{array}{l}\$ 22.2 \mathrm{M}(\mathrm{small} \\
\text { part of ECM \#2) }\end{array}$ & ESPC \\
\hline $\begin{array}{l}\text { INL Project \#3 } \\
\text { (INTEC) }\end{array}$ & $\begin{array}{l}65,467 \\
\text { kgallyr }\end{array}$ & FY 2012 & Unknown & ESPC or UESC \\
\hline INL Project \#4 & $\begin{array}{l}65,467 \\
\mathrm{kgallyr}\end{array}$ & $F Y 2013$ & Unknown & ESPC or UESC \\
\hline INL Project \#5 & $\begin{array}{l}65,467 \\
\mathrm{kgal} / \mathrm{yr}\end{array}$ & FY 2014 & Unknown & ESPC or UESC \\
\hline
\end{tabular}

Notes: 1) ESPC and UESC projects are the primary methods that the INL Site will employ to implement water reduction opportunities.

2) Square footage for FY 2015 is based on the INL's Ten-Year Site Plan and includes $D \& D$ and new construction.

3) INL Project \#1 is an ESPC completed in FY 2000 at the INL Research Center (IRC).

\subsection{Transportation Fuels Management}

\subsubsection{Petroleum Conservation}

The INL Site is one of DOE's largest users of petroleum based fuels. In particular, the INL Site bus fleet contributes to very significant diesel fuel usage.

The INL Site has implemented numerous activities to reduce its usage of petroleum based fuels including leasing new fuel-efficient buses, replacing older existing bus engines with new efficient 4-stroke diesel engines, establishing express bus routes, implementing a "Reduce Engine Idle" campaign, and replacing $8 \%$ of the lightduty fleet to date with new Alternative Fuel Vehicles (AFVs).

The primary focus of the Plan in this area is to reduce the INL Site bus and vehicle fleet's total use of petroleum-based fuel by $2 \%$ each year for a total of $20 \%$ by the end of FY 2015.

Strategies to accomplish this $20 \%$ fleet fuel efficiency improvement may include, but are not limited to:

- Implement the Fueling Infrastructure Improvement project that has been developed for CFA and submitted to DOE EERE for potential funding. 
This project has been estimated at $\$ 830 \mathrm{k}$ and has been reviewed by an NREL fuels reduction team. Upon completion of the defined project, reprogram the individual fueling keys for flex-fuel vehicles to allow for only alternative fuel use.

- INL Site has partnered with NREL to perform a fleet and transportation evaluation and provide a strategy report to reduce petroleum consumption and increase alternative fuel use at the INL Site to meet or exceed the agency goals. Issuance of the final report is expected by the middle of the second quarter of FY 2009.

- INL has been working with the Clean Cities Coalition and third party vendors and fleet management services to determine if it is economically feasible to provide new fueling infrastructure and/or provide alternative fueling services meeting current and future needs. INL is currently awaiting cost estimates based upon discussions of desired infrastructure.

- Develop and implement processes to obtain and use alternative fuels for all INL Site and within Idaho Falls areas in addition to the existing fueling infrastructure locations.

- Develop and implement additional methods to decrease the use of petroleum based fuel and/or decrease the use of petroleum fueled vehicles in the INL fleet with an emphasis on reassigning vehicles to ensure that the most efficient vehicle is assigned for the required task, and evaluating and implementing plans to replace petroleum fueled vehicles with alternative fuel vehicles and electric vehicles as appropriate.

- Maintain a prioritized list of additional cost effective fueling infrastructure improvement or re-location projects to be addressed when internal funding or alternative funding is available.

- Include fuel efficiency topics in the periodic employee communication and encourage the use of the INL bus service and car pooling, educate employees about fueling options and the necessary changes to fleet operations.

- Evaluate new and innovative opportunities including Park and Ride opportunities and employee lots, bus route optimization software, smaller para-transit buses for shuttle service, diesel electric hybrids, CNG powered inter-city coach buses, and a long-term hydrogen fuel study.

\subsubsection{Alternative Fuel Use}

The INL Site has proactively implemented several alternative fuel programs to study and use available alternative fuels in a diverse vehicle fleet at a site with challenging weather extremes. These activities include establishing an LNG/CNG bus and light-duty fueling station and converting 7 buses to LNG fuel, experimenting with biodiesel blends and how the mixtures work in extreme cold temperatures, and establishing a contract with the General Services Agency (GSA) to help obtain AFVs for the light-duty fleet. The INL Site currently uses Liquid Natural Gas (LNG), CNG, Biodiesel 20\% (B20), and Ethanol 85\% (E85) in its vehicle fleet. INL is also considering increased use of flex-fuel vehicles as part of its diverse fleet.

One method to decrease the use of petroleum fuels when vehicle use and mission needs remain the same is to increase the use of alternative fuels. The DOE Order 
requires the increase of alternative fuel by $10 \%$ each year for a total of $100 \%$ by the end of FY 2015.

Strategies to accomplish this $100 \%$ increase in the use of Alternative Fuels/Electric Vehicles may include, but are not limited to:

- Implement the Fueling Infrastructure Improvement project as described in 4.4.1 above and develop additional opportunities for other fueling infrastructure upgrades, modifications, or relocations across the INL Site.

- Reprogram the individual fueling keys for flex-fuel vehicles as described in 4.4.1 above.

- Research and identify cost effective sources of alternative fuels. Strategies to obtain less expensive fuel may include working with other Federal fuel purchasers such as the Defense Energy Support Center (DESC) or to team with other local users to share the costs of shipping alternative fuels from distant locations.

Note: The INL Site has collaborated with several local vendors and organizations to obtain lower cost alternative fuels, including two ethanol vendors, the Yellowstone Business/Transportation Partnership, and the Bannock Planning Organization associated with Ride-Link.

- Develop methods to increase the use of existing alternative fuels including LNG/CNG, biodiesel in the bus fleet during colder weather, and reassigning vehicles to ensure that AFV use is being maximized.

- Maintain a prioritized list of potential fueling infrastructure improvement projects to be addressed when internal funding and/or alternative funding is available.

- Evaluate new and innovative alternative fuel opportunities as outlined in 4.4.1 above.

- Educate the INL workforce through awareness as described in 4.4.1 above.

\subsubsection{Alternative Fuel Vehicles}

Increasing the number and use of AFVs is core to maximizing the use of the proposed updated fueling infrastructure.

Strategies to increasing the use of alternative fuels at INL Site may include, but are not limited to:

- Through GSA, the INL Site will increase the acquisition of alternate fuel vehicles as well as hybrid and plug-in hybrid vehicles when commercially available.

- INL Site will work with GSA to achieve an optimal change out of $20 \%$ of vehicles each year with an emphasis on obtaining E-85 vehicles and smaller, more efficient pickups and sedans.

- INL is working with NREL to obtain $20 \mathrm{CNG}$ buses to replace older inefficient diesel buses. The availability of specialized alternate fuel buses is problematic requiring assistance from other agencies and DOE offices. 


\subsection{High Performance and Sustainable Buildings}

\subsubsection{New Buildings and Major Renovations}

The highest cost component of most buildings is the life-time operating costs. It is very important to consider the operating costs and ways to reducing those costs when designing and constructing new facilities and major renovations.

One of the core functions of Executive Order 13423 and DOE Order 430.2B is to ensure that new buildings are sustainable. INL Site will construct or renovate buildings in accordance with sustainable strategies including resource conservation, energy and cost reduction, and indoor environmental quality.

Strategies to implement Sustainability at the INL Site may include, but are not limited to:

- DOE-ID and INL Site contractors will ensure that all new construction and major renovations are funded, designed, and constructed to achieve Leadership in Energy and Environmental Design (LEED) Gold Certification for all projects over $\$ 5 \mathrm{M}$. They also ensure that projects under the \$5M General Plan Project (GPP) threshold comply with the Guiding Principles for Federal Leadership in High Performance and Sustainable Buildings (Guiding Principles) as outlined in DOE Order 430.2B. Planned construction projects are listed in the INL's Ten-Year Site Plan.

- DOE-ID and INL Site Contractors will ensure that commissioning of buildings and systems is included in all ESPC/UESC projects that result in major revisions of existing facilities.

- The INL Site contractors will update the contractor INL Engineering Standards and other procedural documents as needed to ensure that LEED requirements and/or the Guiding Principles are included in all new building designs and major renovations.

\subsubsection{Existing Infrastructure Sustainability}

Both of the Orders require that $15 \%$ of each site's infrastructure is evaluated and updated to incorporate the sustainable practices of the Guiding Principles for energy and water principles at a minimum. The INL Site has determined that the best facilities to target for implementation of sustainable technologies are the same facilities that are targeted for metering as described in section 4.6 below.

Secretary Bodman issued a memorandum on February $29^{\text {th }}, 2008$ that reinforced this requirement and required all programs to implement a plan to ensure that $15 \%$ of the enduring buildings are in compliance by 2015.

Strategies to implement Sustainable Practices and Design in 15\% of the INL Site existing and enduring infrastructure by the end of FY 2015 may include, but are not limited to:

- Ensure that the ESPC/UESC process uses the Guiding Principles to perform the evaluations and to determine the cost and feasibility of performing upgrades. Then use the ESPC/UESC funding vehicle to perform the upgrades as cost effective. 
- For upgrades that are not feasible to attach to an ESPC/UESC project, prepare project proposals for DOE FEMP funding as described in the Guiding Principles and include the cost and operations impact of implementation and a path forward.

- Secure other funding and incentive opportunities such as FEMP direct funding, Idaho Power Industrial Efficiency Incentive funding, and Idaho Falls Power project implementation funding.

- Leverage the ESPC/UESC processes to accomplish energy audits of INL Site facilities at a rate of $25 \%$ each year.

\subsubsection{New and Existing Building Leases}

Many opportunities are lost when a lease is signed without first determining upgrades that should be made to ensure that the facility will be efficient and that employees will be comfortable and productive.

Strategies to capture these opportunities may include, but are not limited to:

- Incorporate the LEED requirements and/or guiding principles into new build-to-lease solicitations.

- Develop a checklist and engineering walkthrough process to evaluate an existing facility prior to negotiating a new or renewed lease.

- Compile a list of upgrades that should be negotiated before leases are finalized.

- Use UESC on leased facilities when term of payback does not exceed lease duration.

\subsection{Advanced Metering}

Advanced metering is required to be installed by the end of FY 2012 as far as is practicable. Practicable is defined as conforming to the DOE Buildings Electric Metering Guidance, September 27, 2006, FEMP Document \#2006.100 Rev 0.

The INL Site contractors have performed an analysis on all existing infrastructure that will still be in place by 2015 . That analysis used the Guidance to identify 48 buildings managed by the INL contractor, 16 buildings managed by the ICP contractor and 4 buildings managed by the AMWTP contractor that may be cost effective to meter.

Strategies to ensure that the data collected by the new metering network is effectively used at the INL may include, but are not limited to:

- Ensure that selected metering systems are compatible with the INL's existing metering and information technologies infrastructure and integrate with FEMP's central metering information collection system as described in DOE Order 430.2B.

- Develop reports or assess methods to best disseminate the metered data for project energy use baseline development, and for identifying and validating energy reduction opportunities and projects.

Table 4 includes the buildings that have been selected for Advance Meter installation consideration. 
Table 4. List of Buildings Selected for Advanced Meter Installation Consideration

\begin{tabular}{|c|c|c|c|c|c|c|}
\hline CFA & \multicolumn{2}{|c|}{ MFC } & TAN & $\begin{array}{c}\text { ATR } \\
\text { Complex } \\
\end{array}$ & WMF & INTEC \\
\hline CF-609 & MFC-701 & MFC-782 & TAN-629 & TRA-605 & WMF- $610^{2}$ & CPP- $602^{1}$ \\
\hline CF-621 & MFC-704 & MFC-784 & TAN-675 & TRA-628 & WMF- $635^{2}$ & CPP- $604^{1}$ \\
\hline CF-623 & MFC-710 & MFC-785 & TAN-677 & TRA-632 & WMF- $636^{2}$ & CPP- $606^{1}$ \\
\hline CF-666 & MFC-725 & MFC-787 & TAN-679 & TRA-652 & WMF- $637^{1}$ & CPP- $630^{1}$ \\
\hline CF-690 & MFC-752 & MFC-788 & TAN-679A & TRA-653 & WMF- $676^{2}$ & CPP- $659^{1}$ \\
\hline CF-696 & MFC-753 & MFC-791 & TAN-681 & TRA-670 & WMF- $697^{1}$ & CPP- $663^{1}$ \\
\hline CF-698 & MFC-759 & MFC-792 & & & WMF-1612 & CPP- $666^{1}$ \\
\hline CF-1611 & MFC-765 & MFC-792A & & & WMF-1614 & CPP- $684^{1}$ \\
\hline CF-1612 & MFC-765A & MFC-793 & & & & CPP-691 ${ }^{1}$ \\
\hline CF-1618 & MFC-768 & MFC-793C & & & & CPP- $1604^{1}$ \\
\hline EBR1-601 & MFC-772 & MFC-798 & & & & CPP- $1605^{1}$ \\
\hline & MFC-774 & MFC-799 & & & & CPP- $1631^{1}$ \\
\hline & MFC-781 & & & & & IWTU $^{1}$ \\
\hline
\end{tabular}

Notes: 1) The buildings with a ${ }^{l}$ are currently managed by the ICP contractor; the buildings with $a^{2}$ are managed by the AMWTP contractor; all others are managed by the INL contractor.

2) It is anticipated that, upon further evaluation, advanced metering may not be cost effective for all of the selected buildings and that others may be added to the list.

3) The current plans for CPP-602 and CPP-630 are for those buildings to be in a cold standby condition by the end of CY 2012, therefore, metering may not be warranted.

- These 69 facilities represent a total of over $2,633,516 \mathrm{ft}^{2}$ or $48 \%$ of the INL Site's projected 5,473,304 $\mathrm{ft}^{2}$ in FY 2015.

- Actual Energy Use Intensity and Blended Electric Unit Costs were applied to the Guidance charts to determine a minimum building size of $11,000 \mathrm{ft}^{2}$ for inclusion in the INL's metering installation plan.

- Because these facilities represent the highest potential for cost effective energy retrofits, they have been updated in the FIMS database to indicate that they will be targeted for sustainable upgrades using the Guiding Principles as highlighted in section 4.5.1.

- Energy savings using an estimated $2 \%$ energy reduction per meter installation would result in over $\$ 94 \mathrm{k}$ annually.

- 25 of these 69 meters will be installed as part of the MFC ESPC project.

- DOE-ID and INL Site contractors will use this analysis to ensure that the additional 43 buildings are included in future ESPC or UESC projects and are connected and integral to the metering network that will be installed as part of the MFC ESPC project. 


\subsection{Environmental Management System}

The INL Site uses the Environmental Management System (EMS) as the primary management approach for addressing environmental aspects of internal agency operations and activities, including environmental aspects of energy management and transportation functions.

\subsubsection{Management Systems}

DOE-ID and the INL Site contractors have implemented Environmental Management Systems and already have or are actively integrating the energy and transportation management aspects in their respective programs.

Strategies to further integrate energy and transportation fuels goals in the INL Site's Environmental Management System (EMS) may include, but are not limited to:

- Implementing the EMS as the primary management approach for addressing environmental aspects of INL operations and activities including the environmental aspects of energy and transportation functions, establishment of INL objectives and targets, and collection, analysis, and reporting of information to measure performance.

- Fully integrating the EMS with other management systems to assure effective coordination of all programs and management systems in achieving INL environmental objectives.

- Maintaining the EMS as conforming to a consensus EMS standard such as ISO 14001 as described by DOE Order 450.1A. An EMS conforming to such a standard demonstrates senior management involvement and awareness of the EMS and its operation.

\subsubsection{Electronics Management}

The Federal Electronics Challenge (FEC) is a voluntary partnership program that encourages agencies to manage their electronics in an environmentally sound manner during all three life-cycle phases: acquisition and procurement, operation and maintenance, and end-of-life management. INL Site joined the FEC as a facility partner in 2007. The INL Site participation is identified and discussed in DOE/ID-10333.

Strategies to continuously improve environmental stewardship of electronic assets at the INL Site include, but are not limited to:

- Submit fiscal year goals for the INL Site to the FEC.

- Work with the INL Site contractors Property Management, Procurement, Information Technologies (IT) groups, and DOE-ID each year to assemble an award application package for submittal to FEC.

- Maintain the INL Site's FEC Bronze rating at a minimum. Evaluate and develop goals as applicable to increase the FEC rating from Bronze to Silver beginning in FY 2009 and seek to maintain this rating or higher in each year through FY 2015.

- Purchase environmentally preferable electronic equipment including computer desktops, laptops, and monitors registered under the Electronic Product Environmental Assessment Tool (EPEAT ${ }^{\mathrm{TM}}$ ). 
- Encourage and/or mandate the installation and use of energy conservation settings on all Personal Computers and implement an after-hours powerdown requirement as applicable depending upon computer use. Use internal Information Technologies (IT) organizations to implement these requirements.

\subsubsection{Procurement}

DOE-ID and the INL contractors maintain an affirmative procurement program that assists in purchasing environmentally preferable products wherever possible. The INL Site affirmative procurement program is identified and discussed in DOE/ID10333.

Strategies of this program include, but are not limited to:

- Continue participation with the Federal Electronics Challenge (FEC).

- Ensure that $100 \%$ of all monitors purchased are ENERGY STAR® compliant

- Include ENERGY STAR® requirements in the special terms and conditions in $30 \%$ of all contracts.

- Meet all Federal regulations and executive orders for electric equipment that address energy efficiency.

- Establish and promote a policy to power off PCs when employees leave for the work day.

- Use the Electronic Product Environmental Assessment Tool (EPEAT ${ }^{\mathrm{TM}}$ ) to evaluate, compare, and select desktop computers, laptops, and monitors based on their environmental performance throughout their life cycle with a goal of that at least $95 \%$ purchased are EPEAT ${ }^{\mathrm{TM}}$ registered.

Notes: Complimentary to the FEC, EPEAT ${ }^{\mathrm{TM}}$ evaluates electric products according to three tiers of environmental performance (Bronze, Silver, and Gold) based on the level of product conformance to multiple mandatory and optional performance categories. The EPEAT ${ }^{\mathrm{TM}}$ performance categories are:

- Reduction / Elimination of Environmentally Sensitive Materials

- Materials Selection

- Design for End of Life

- Product Longevity / Life Extension

- Energy Conservation

- End-of Life Management

- Corporate Performance

- Packaging.

All of the desktops, laptops, and monitors that are listed as standard machines on the current contractors' blanket purchasing agreement are EPEAT ${ }^{\mathrm{TM}}$ Silver or better. 


\subsubsection{Pollution Prevention}

Pollution Prevention (P2) and sustainability is as identified in DOE/ID-10333. Various activities have been successfully implemented at the INL Site including affirmative procurement, waste reduction, materials reuse, and materials recycling programs.

Pollution prevention at the INL Site will continue to be encouraged by, but not limited to:

- Enhancing communication of P2 and Sustainability objectives, goals, methods, and ideas laterally and vertically among INL Site organizations and contractors.

- Promoting integration and coordination between waste generators and waste managers on P2 waste minimization matters.

- Identifying and modifying policies, procedures, or practices that may be barriers to $\mathrm{P} 2$.

- Creating incentives for recognition of employees who excel in the area of P2.

- Complying with Federal, State, and local regulations and DOE requirements for $\mathrm{P} 2$.

- Reducing or eliminating the generation of waste streams through source reduction and substitution, product reformulation, improved housekeeping, inventory control, process modification, and onsite reuse and recycling of materials.

- Identifying and implementing new methods and technologies to improve P2 and Sustainable practices at the INL Site.

- Promoting the use of non-hazardous materials in plant construction, maintenance, and operations to minimize the risks to human and environmental health.

- Collecting and exchanging P2 information from fellow DOE laboratories and other appropriate sites through technology transfer, outreach, and educational networks.

\section{EMERGENCY CONSERVATION PLANS}

Historically, the INL Site has experienced very few actual power outages, the longest of which only lasted several hours while all backup and emergency power systems operated as designed with no issues. There is no formal Emergency Conservation Plan as the INL Site grid is a simple extension of the commercial grid and the INL Site has a secure power agreement with Idaho Power.

The INL contractor is contractually required to develop, implement, and update a Continuity of Operations Program (COOP) designed to assist DOE-ID in continuing to accomplish DOE's mission essential functions, primary mission essential functions, and essential supporting activities. As part of the COOP site plan, steps will be in place to ensure only those functions deemed essential are operational. Conservation measures will allow essential functions to operate for 3, 5, 7, or 30 days. An informal Emergency Conservation Plan has been developed but has not yet been formalized. 


\section{EMPLOYEE RESPONSIBILITIES}

The habits and actions of our employees are an integral part of the Plan. All energy using equipment is in place for the comfort and/or productivity of the employees. No controls or engineered systems can determine when employees need to use energy as well as can the employees themselves. There are several actions that all employees can take to significantly reduce energy waste and taxpayer dollars needed for utility costs at the INL Site.

- Education, awareness, and surveys of office and work areas can assist in ensuring that all nonessential lighting, personal computers, equipment, and other systems are turned off when not needed. Diligence with these activities when leaving for the day or an extended period during the work day can truly make a difference.

- Realization that real and significant energy savings requires an effort on the part of facilities personnel. Accept and work with the changes that the INL Site needs to make to the facilities and facility control systems.

- Reduction in use of government passenger vehicles between the on-site and in-town facilities by maximizing utilization of existing shuttle buses and taxi systems. If a government vehicle must be used, the light vehicle pool coordinators are directed to identify and encourage car pooling whenever possible.

Note: Bus shuttles have been scheduled with almost hourly service throughout the workday and a ticket is not needed.

- Scheduling meetings to align with bus shuttle schedules as much as possible.

- Maximizing the use of alternate fuel in all government vehicles that are bi-fuel capable.

\section{APPENDICES}

\subsection{Appendix A - Glossary}

Alternative Fuel - A vehicle or equipment fuel that is either not petroleum based or significantly reduces the petroleum content of the fuel. Biodiesel blends such as B20 (20\% biodiesel) and Ethanol blends such as E85 (85\% Ethanol) are the more common alternative fuels. Compressed natural gas $(\mathrm{CNG})$ and liquefied natural gas (LNG) are also recognized alternative fuels that are not a blended fuel.

Alternative Fuel Vehicle - Alternative fuel vehicles (AFV) are specially designed to run on an alternative fuel. They can be dedicated to a single alternative fuel such as LNG, or they can be dual fuel capable of operating on both alternative such as CNG or E85 and gasoline. Diesel engine vehicles that can simply be operated on a biodiesel blend are usually not considered AFVs.

Commissioning - A process of ensuring that all building systems are installed and perform interactively according to the design intent, the systems are efficient and cost effective and meet the owner's operational needs, and the installation is adequately documented and that the operators are adequately trained.

Commissioning Authority - The individual hired by, or responsible to, the building owner and is tasked with implementing the commissioning process for a new or existing building. The Commissioning Authority is typically responsible for all aspects of the commissioning process, leads and trains the commissioning team, and witnesses or verifies all system checks or 
inspections throughout the process. The Commissioning Authority has final jurisdiction for the entire commissioning process.

Continuous Commissioning - Continuous commissioning involves ongoing monitoring and testing of systems as part of a regular maintenance plan to ensure optimum performance and enhanced equipment longevity. Continuous commissioning can be at a system or a building level depending upon the requirements of the stakeholders.

Energy Efficiency - The ability of a building to minimize the amount of energy used for employee safety, health, and comfort. Energy efficiency also applies to the processes that are performed inside the building, which are not necessarily part of the physical structure. Energy efficiency improvements should always be measured by life cycle cost effectiveness, and not by first cost or simple payback.

ESPC - Energy Savings Performance Contracts (ESPC) are projects that are developed, engineered, performed, and funded by an outside contractor called an Energy Services Contractor (ESCo). ESPCs are paid for through the energy savings derived from the project and are intended to be a no-cost turn-key process or project. The annual payments are made to the ESCo with funds that would have been distributed to the utility. ESPCs are especially useful when capital funding is not readily available. DOE sites can take advantage of the Super ESPC program which provides pre-evaluated ESCos familiar with Federal processes.

$H V A C$ - Heating, ventilating, and/or air conditioning (cooling) systems in a building. HVAC systems include all components, controls, and distribution systems needed to deliver conditioned air to the desired point of use.

Indoor Environment - A building's indoor environment includes many factors including the quality of the air in and supplied to the building, temperature levels and consistency throughout the building, amount of pollutants in the work space, lighting levels and quality, levels of unwanted sound, and amount of day lighting.

INL Site - All contractors and activities at the INL Site under the control of the DOE-ID Operations Office which excludes the Naval Reactors Facility (NRF).

LEED ${ }^{\mathrm{TM}}$ Rating System - Leadership in Energy and Environmental Design (LEED) is a tool for green building design to help design teams and owners determine green project goals, identify green design strategies, measure and monitor progress, and document success. The LEED ${ }^{\mathrm{TM}}$ Rating System was developed and is administered by the U.S. Green Building Council (USGBC), which is a national non-profit organization that includes representation from all aspects of the building industry. The LEED ${ }^{\mathrm{TM}}$ Rating System is a point system of five technical categories and four levels of certification: LEED Certified, Silver, Gold, and Platinum.

Low-Cost-Low Cost modifications or repairs may be performed during the commissioning process, but are typically implemented shortly after. Low-cost opportunities typically cost less than $\$ 500$ and can be accomplished in bundled groups.

No-Cost-Adjustments or modifications that can be made during the commissioning implementation phase by in-house crafts. These on-the-spot modifications are essentially no-cost other than the time for the craft person to be available. No-cost adjustments should be maximized during the implementation phase.

Re-commissioning - Commissioning that is performed several years after a building, which was previously commissioned, has been in operation to ensure that the building and systems are 
meeting the original design requirements. Re-commissioning is typically used to identify and correct malfunctions in a building that occur as the building ages and to ensure continued indoor air quality, employee productivity, and energy efficiency. Re-commissioning can also be used to address changes in ownership, building use patterns, and operation and maintenance practices. A building's use and mission often change during the building's life and these changes necessitate the need for re-commissioning to ensure that the building is capable of efficiently meeting its new and/or evolving mission.

Retro-commissioning - Applying the commissioning process to a building that has never been commissioned. Retro-commissioning is sometimes referred to as "Existing Building Commissioning" and is used to compare the building's original design parameters and operational criteria with current design and operational requirements. Retro-commissioning determines if the building is capable of meeting its current mission needs and identifies modifications required to meet those needs. Retro-commissioning then identifies upgrades to the building that will enhance its energy efficiency, tenant comfort and productivity, and indoor air quality. Retro-commissioning as a best Practice means using a whole building approach to ensure that the building is operating within well-defined criteria established by the building stakeholders.

Sustainability - The ability of a society to operate indefinitely into the future without depleting its resources. Sustainability includes concepts of green building design and construction, reuse and recycling of materials, reduced use of material and energy resources for building construction and operation, water conservation, and responsible stewardship of the environment adjacent to the building. 